I personally deplore the practice of breast augmentation by injection of foreign material with its attendant risk of masking the appearance of a carcinoma ; this, however, is not a valid reason for condemning the silicones, which, if properly used in pure form and carefully handled to avoid contamination, are extraordinarily inert and may prove to be the most useful and safest of the implant materials we have at our disposal.-I am, eic.,

London $\mathbb{W} .1$

\section{B. Helal.}

REFERENCES

4 Ashley, F. L., Braley, S., Rees, T. D., Goulian, D., and Ballantyne, D. L., Plast. Reconstr.

= Ben-Hur, 1967, 39, 411. ., and Neuman, Z., Israel med. 7., 1963, 22, is.

Grasso, P., Goiberg, L., and Fairweather, F. A.. Lancet, 1964, 2, 96.

Kagan, H. D., Arch. Otolaryng. 1963, 78, 663. Little, K., and Parkhouse, J., Lancet, 1962, 2. Rees, T. D., Platt, J., and Ballantyne,

Plast. Reconstr. Surg.
Rowe, V. K., Spencer, H. C., 35, 131.
Bass, S. L.,

- F. industr.' Hyg. 1948, $30,332$. Rowe, V. K., Spencer, H. C., and Bass, S. L.,
Arch. industr. Hyg., 1950, 1, 539 .

\section{E.E.G. Signs of Death}

SIR,-Following your leading article on this subject (1t May, p. 318) I wrote (1 June, p. 557) adding some points relevant to our present study of the borderland between life and death and quoted some additional literature contains little information about joint considered these quotations to consist "largely of anecdote or of opinion published in society proceedings." May I point out that the work of the French authors I quoted ${ }^{1-4}$ is highly respected by whoever is reasonably familiar with the study of E.E.G. in the borderland between life and death. We still have a great deal to learn from many sources, in many languages, as to how the brain works in health and disease.

As to my proposals for the creation of a mobile E.E.G. unit to study resuscitated patients in various hospitals, constructive remarks will be welcome. However, Dr. Binnie's comments as to the quality of the work of such a unit "offering ill-founded and largely speculative opinions in the middle of the night" are not based on facts, as such a unit does not yet exist. A third point to which serious thought should be given is what Dr. Binnie calls "the E.E.G. diagnosis of death." E.E.G. may offer fundamental information about either recoverable or non-recoverable cerebral function, while the patient may be kept alive by various means. How can E.E.G. be expected "to diagnose death" ?-I am, etc.,

Hospital for Sick Children,

\section{G. Pampiglione.}

London W.C.1.

\section{REFERENCES} Wertheimer, P., Jouvet, M., and Descartes, J.,
Presse méd.,'1959, 67, 87.

Fischgold, H., and Mathis, P., Electroenceph. clin. Neurophysiol., 1959, Suppl. 11.

- Arfel, G., and Fischgold, H., Electraenceph. clin. Neurophysiol., 1961, 13, 653 .

- Vigouroux, R. P., Marseille chir., 1966, 18, 6.

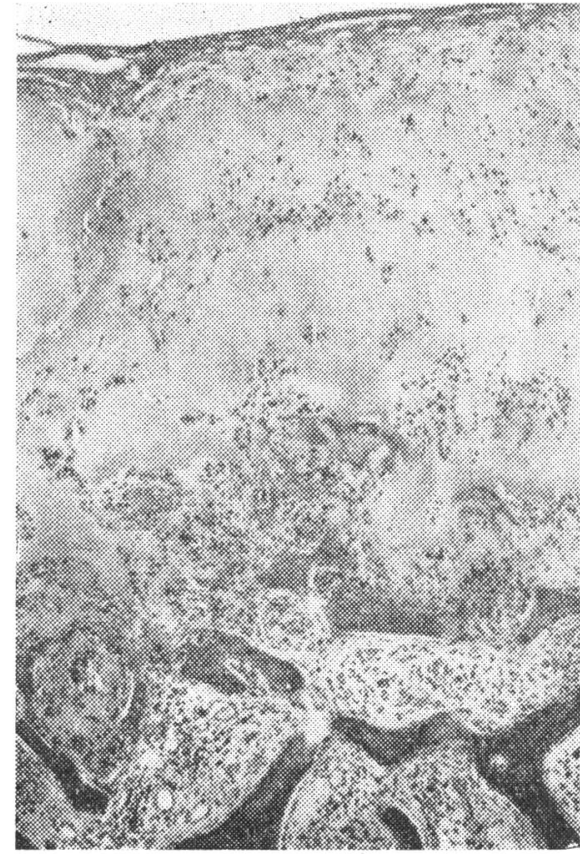

FIG. 2

tion of the process occurring in rheumatoid arthritis differs importantly from that based on earlier studies in which conclusions were drawn from cases with advanced destructive disease.-I am, etc.,

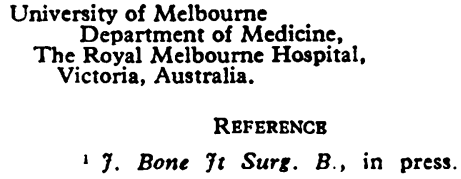

REFERENCE

1 f. Bone $f_{t}$ Surg. B., in press.

\section{Anaemia and Hiatus Hernia}

SIR,-I was very interested to read the article concerning iron absorption and daily blood loss in patients suffering from anaemia as a complication of hiatus hernia (6 July, p. 22). I enjoyed this article but wish to disagree with the authors' conclusions in the last paragraph.

Patients with sliding hernia occasionally present with large haematemeses sufficient to endanger their lives, and oral iron will hardly deal with this emergency. Although continuous oral iron may well keep the anaemia under control, nevertheless the hernia is still present and therefore the other major complications of spill-over pneumonitis and stricture are still liable to occur. Also there is some evidence to show that the incidence of carcinoma of the lower oesophagus may be slightly higher in patients with a sliding hernia than in those without this condition.

I believe that the complications of hiatus hernia, of which anaemia is only one, are potentially so serious that all patients with this condition should be considered for surgical repair, and if this repair is carried out through a lower thoracotomy then the morbidity and mortality rate of the operation is negligible.-I am, etc.,

Michael Bates.

Department of Thoracic Surgery,

North Middlesex Hospital,
London N.18. 